\title{
Influence of NPK Levels on Performance of Indian Mustard (Brassica juncea L.)
}

\author{
A.L. Jat*, K.P. Prajapati, B.K. Patel, P.J. Patel, J.R. Patel, S.K. Shah and A.G. Desai \\ Castor-Mustard Research Station, Sardarkrushinagar Dantiwada Agricultural University, \\ Sardarkrushinagar - 385 506, Gujarat, India \\ *Corresponding author
}

\section{A B S T R A C T}

\begin{tabular}{|l|}
\hline K e y w or d s \\
Indian mustard, \\
Nitrogen, \\
Phosphorus, \\
Potassium, Partial \\
factor productivity \\
and production \\
efficiency.
\end{tabular}

\section{Introduction}

India is the fourth largest oilseed economy in the world. Rapeseed-mustard contributes $28.6 \%$ in the total oilseeds production among the seven edible oilseeds cultivated in India and ranks second after groundnut sharing $27.8 \%$ in the India's oilseed economy (Singh et al., 2017). Indian mustard (Brassica juncea L.) is predominantly cultivated in the states of Rajasthan, Uttar Pradesh, Haryana, Madhya Pradesh and Gujarat and some non-traditional areas of South India including Karnataka, Tamil Nadu, and Andhra Pradesh. The mustard growing regions in India are having vast diversity in the agro climatic conditions and different species of rapeseed-mustard are grown in some part of the country. Gujarat stands second in yield among the mustard growing states in India. In Gujarat important mustard growing districts in north Gujarat are Banaskantha, Patan, Mahesana, Sabarkantha, Kutchh and Gandhinagar districts covered nearly $95 \%$ of total mustard growing area of Gujarat state. Although a number of factors are responsible for low productivity mainly imbalance fertilization. Apart from improved varieties and judicious use of irrigation water without accompanying use of adequate amount of nutrients leads to nutrient mining and imbalance, resulting in now a day we are facing crisis of low soil fertility, hidden 
hunger and low factor productivity. Optimum amount and balanced fertilization is critically required for achieving higher yield from improved variety of Indian mustard. Primary nutrients i.e. nitrogen, phosphorus and potassium play a pivotal role in crop yield. Various studied indicated that the increasing levels of nutrient resulted concomitantly increasing yield of mustard. Therefore, this study was initiated to evaluate the various levels of nutrients on the productivity, profitability and quality of Indian mustard.

\section{Materials and Methods}

A field experiment was conducted during rabi season of 2015-16 at Castor-Mustard Research Station, Sardarkrushinagar Dantiwada Agricultural University, Sardarkrushinagar $\left(24^{\circ} 12^{\prime} \mathrm{N}\right.$ latitude, $72^{\circ} 12^{\prime}$ E longitude and at an altitude of $154.5 \mathrm{~m}$ above mean sea level), Gujarat, India. The soil of the experimental field was loamy sand in texture with $\mathrm{pH}$ 7.2, low in available nitrogen, available phosphorus, available potassium and organic carbon. The experiment was laid out in randomized block design with factorial concept comprising three levels of nitrogen, two levels phosphorus and two levels of potassium with replicated thrice. The mustard variety 'GM-3' was sown in the last week of October at a distance of $45 \mathrm{~cm} \mathrm{x}$ $15 \mathrm{~cm}$ by using $3.5 \mathrm{~kg} / \mathrm{ha}$ seed rate. Full dose of phosphorus and potassium along with half dose of nitrogen fertilizers were drilled just before the sowing in the form of urea, DAP and MOP and remaining half dose of nitrogen was applied after 25-30 DAS in earmarked plots. $40 \mathrm{~kg}$ sulphur/ha was also applied uniformly to all plots as basal application. The other crop management practices were followed as per standard package of practices. Various growth parameters, yield attributes and yield were recorded at harvest. Oil content was analyzed by standard procedures of Nuclear Magnetic Resonance Method. The cost of cultivation and net returns were calculated by taking into account the prevailing cost of inputs and local market price of produce. The standard analysis of variance (Gomez and Gomez, 1984) technique prescribed for the randomized block design was performed to compare the treatment means at 5\% level of significance $(\mathrm{P}=0.05)$ using least significant difference (LSD).

\section{Results and Discussion}

\section{Crop growth, yield and quality}

Plant height, number of branches/plant, number of seeds/siliqua and length of siliqua were not influenced significantly due to various levels of nitrogen, phosphorus and potassium except number of primary branches/plant and number of siliquae/plant which were significantly higher with the application of $80 \mathrm{~kg} \mathrm{~N} / \mathrm{ha}$ followed by $100 \mathrm{~kg}$ N/ha (Table 1). While, number of seeds/siliqua was recorded higher under application of $100 \mathrm{~kg} \mathrm{~N} / \mathrm{ha}$ and it's remained statistically at par with application of $80 \mathrm{~kg}$ N/ha. The 1000-seed weight remained unaffected due to various levels of NPK. The results are in line with the findings of Singh et al., (2017). The oil content and oil yield was not influenced significantly due to different levels of nitrogen, phosphorus and potassium. However, oil yield was recorded significantly higher with the application of $80 \mathrm{~kg} \mathrm{~N} / \mathrm{ha}$ which was closely followed by incorporation of $100 \mathrm{~kg} \mathrm{~N} / \mathrm{ha}$. Significantly higher seed yield was recorded with the application of 80 $\mathrm{kg} \mathrm{N} / \mathrm{ha}$ and it was closely followed by 100 $\mathrm{kg} \mathrm{N} / \mathrm{ha}$. The corresponding increases in seed yield due to application of $80 \mathrm{~kg} \mathrm{~N} / \mathrm{ha}$ to the tune of 4.40 and $11.54 \%$ higher over $100 \mathrm{~kg}$ and $60 \mathrm{~kg} \mathrm{~N} / \mathrm{ha}$. This could be ascribed due to the more availability of nitrogen at $80 \mathrm{~kg} / \mathrm{ha}$ must have increased the proportion of nutrient in the crop plant. Beside this, the higher level of nutrient resulted in higher yield attributes and led to increased seed yield of mustard. 
Int.J.Curr.Microbiol.App.Sci (2017) 6(9): 1986-1990

Table.1 Effect of NPK levels on growth, yield attributes and quality of Indian mustard

\begin{tabular}{|c|c|c|c|c|c|c|c|c|c|c|}
\hline \multirow[t]{2}{*}{ Treatments } & \multirow{2}{*}{$\begin{array}{c}\text { Plant } \\
\text { height } \\
(\mathrm{cm})\end{array}$} & \multicolumn{2}{|c|}{ No. of branches/plant } & \multirow{2}{*}{$\begin{array}{c}\text { No. of } \\
\text { siliquae } \\
\text { per plant }\end{array}$} & \multirow{2}{*}{$\begin{array}{l}\text { No of } \\
\text { Seeds/ } \\
\text { siliqua }\end{array}$} & \multirow{2}{*}{$\begin{array}{l}\text { Length of } \\
\text { siliqua } \\
\text { (cm) }\end{array}$} & \multirow{2}{*}{$\begin{array}{c}\text { Test } \\
\text { weight } \\
(\mathrm{g})\end{array}$} & \multirow{2}{*}{$\begin{array}{c}\text { Seed } \\
\text { yield } \\
\text { (kg/ha) }\end{array}$} & \multirow{2}{*}{$\begin{array}{c}\text { Oil } \\
\text { Content } \\
(\%)\end{array}$} & \multirow{2}{*}{$\begin{array}{c}\text { Oil } \\
\text { yield } \\
(\mathrm{kg} / \mathrm{ha})\end{array}$} \\
\hline & & Primary & Secondary & & & & & & & \\
\hline \multicolumn{11}{|l|}{ Nitrogen levels } \\
\hline $\mathrm{N}_{1}: 60 \mathrm{~kg} / \mathrm{ha}$ & 185.98 & 4.70 & 13.80 & 360.07 & 14.05 & 3.96 & 4.44 & 2703 & 36.21 & 979 \\
\hline $\mathrm{N}_{2}: 80 \mathrm{~kg} / \mathrm{ha}$ & 187.85 & 5.15 & 14.22 & 388.57 & 14.92 & 4.18 & 4.22 & 3015 & 36.57 & 1102 \\
\hline $\mathrm{N}_{3}: 100 \mathrm{~kg} / \mathrm{ha}$ & 188.08 & 4.83 & 13.87 & 382.22 & 14.95 & 4.17 & 4.27 & 2888 & 35.59 & 1028 \\
\hline $\mathrm{SEm} \pm$ & 4.14 & 0.12 & 0.53 & 7.75 & 0.23 & 0.89 & 0.14 & 62.06 & 0.42 & 30.9 \\
\hline $\mathrm{CD}(\mathrm{P}=0.05)$ & NS & 0.35 & NS & 22.75 & 0.69 & $\mathrm{NS}$ & NS & 182.08 & $\mathrm{NS}$ & 90.5 \\
\hline \multicolumn{11}{|c|}{ Phosphorus levels } \\
\hline $\mathrm{P}_{1}: 20 \mathrm{~kg} / \mathrm{ha}$ & 186.24 & 4.83 & 14.23 & 365.53 & 14.56 & 4.06 & 4.40 & 2812 & 36.27 & 1020 \\
\hline $\mathrm{P}_{2}: 40 \mathrm{~kg} / \mathrm{ha}$ & 188.37 & 4.96 & 13.69 & 388.37 & 14.72 & 4.15 & 4.21 & 2926 & 35.97 & 1052 \\
\hline SEm \pm & 5.07 & 0.15 & 0.65 & 6.33 & 0.19 & 0.073 & 0.12 & 50.67 & 0.34 & 37.8 \\
\hline $\mathrm{CD}(\mathrm{P}=0.05)$ & NS & NS & NS & 18.58 & $\mathrm{NS}$ & NS & NS & NS & NS & $\mathrm{NS}$ \\
\hline \multicolumn{11}{|c|}{ Potassium levels } \\
\hline $\mathrm{K}_{0}: 0 \mathrm{~kg} / \mathrm{ha}$ & 187.73 & 4.93 & 14.08 & 376.70 & 14.74 & 4.08 & 4.26 & 2895 & 36.19 & 1048 \\
\hline $\mathrm{K}_{1}: 30 \mathrm{~kg} / \mathrm{ha}$ & 186.88 & 4.86 & 13.84 & 377.20 & 14.53 & 4.12 & 4.35 & 2843 & 36.06 & 1024 \\
\hline $\mathrm{SEm} \pm$ & 5.07 & 0.15 & 0.65 & 6.33 & 0.19 & 0.073 & 0.12 & 50.67 & 0.34 & 37.8 \\
\hline $\mathrm{CD}(\mathrm{P}=0.05)$ & NS & NS & NS & NS & NS & NS & NS & NS & NS & NS \\
\hline
\end{tabular}


Int.J.Curr.Microbiol.App.Sci (2017) 6(9): 1986-1990

Table.2 Effect of NPK levels on economics and partial factor productivity of Indian mustard

\begin{tabular}{|c|c|c|c|c|c|c|}
\hline \multirow[t]{2}{*}{ Treatments } & \multirow[t]{2}{*}{$\begin{array}{l}\text { Net returns } \\
\text { (₹/ha) }\end{array}$} & \multirow[t]{2}{*}{ B: $\mathrm{C}$ ratio } & \multirow{2}{*}{$\begin{array}{l}\text { Production } \\
\text { efficiency } \\
\text { (kg/ha/day) }\end{array}$} & \multirow{2}{*}{$\begin{array}{l}\text { Economic } \\
\text { efficiency } \\
\text { (₹/ha/day) }\end{array}$} & \multicolumn{2}{|c|}{$\begin{array}{c}\text { Partial factor productivity } \\
\text { (kg yield/kg nutrient applied) }\end{array}$} \\
\hline & & & & & Nitrogen & Phosphorus \\
\hline \multicolumn{7}{|l|}{ Nitrogen levels } \\
\hline $\mathrm{N}_{1}: 60 \mathrm{~kg} / \mathrm{ha}$ & 75128 & 4.01 & 19.9 & 552 & 45.1 & 99.0 \\
\hline $\mathrm{N}_{2}: 80 \mathrm{~kg} / \mathrm{ha}$ & 86387 & 4.44 & 22.2 & 635 & 37.7 & 112.6 \\
\hline $\mathrm{N}_{3}: 100 \mathrm{~kg} / \mathrm{ha}$ & 81436 & 4.21 & 21.2 & 599 & 28.9 & 109.0 \\
\hline $\mathrm{SEm} \pm$ & 2653.0 & 0.11 & 0.53 & 19.5 & 0.94 & 2.73 \\
\hline $\mathrm{CD}$ at $5 \%$ & 7781.0 & 0.31 & 1.55 & 57.2 & 2.77 & 8.00 \\
\hline \multicolumn{7}{|c|}{ Phosphorus levels } \\
\hline $\mathrm{P}_{1}: 20 \mathrm{~kg} / \mathrm{ha}$ & 79362 & 4.22 & 20.7 & 584 & 36.2 & 140.6 \\
\hline $\mathrm{P}_{2}: 40 \mathrm{~kg} / \mathrm{ha}$ & 82606 & 4.22 & 21.5 & 607 & 38.2 & 73.1 \\
\hline $\mathrm{SEm} \pm$ & 3249.3 & 0.13 & 0.65 & 23.9 & 1.16 & 3.34 \\
\hline $\mathrm{CD}$ at $5 \%$ & NS & NS & NS & NS & 3.39 & 9.79 \\
\hline \multicolumn{7}{|c|}{ Potassium levels } \\
\hline $\mathrm{K}_{0}: 0 \mathrm{~kg} / \mathrm{ha}$ & 82379 & 4.33 & 21.3 & 606 & 37.4 & 107.9 \\
\hline $\mathrm{K}_{1}: 30 \mathrm{~kg} / \mathrm{ha}$ & 79589 & 4.11 & 20.9 & 585 & 37.0 & 105.8 \\
\hline SEm \pm & 3249.3 & 0.13 & 0.65 & 23.9 & 1.16 & 3.34 \\
\hline $\mathrm{CD}$ at $5 \%$ & NS & NS & NS & NS & NS & NS \\
\hline
\end{tabular}


Similar increase in yield due to increase in levels of fertilizers have also been reported by Ghimire and Bana (2011).

\section{Economics}

Net returns ( $₹$ 86387/ha) and benefit: cost ratio (4.44) was recorded higher with application of 80 kg N/ha (Table 2). It gave ₹ 4951/ha and ₹ $11259 /$ ha higher net monetary returns over the $100 \mathrm{~kg}$ and $60 \mathrm{~kg} \mathrm{~N} / \mathrm{ha}$. Application of $80 \mathrm{~kg} \mathrm{~N} / \mathrm{ha}$ showed mark improvement in seed yields and thus gaining more profit in terms of net returns and benefit: cost ratio over rest of treatments. Phosphorus applied at $40 \mathrm{~kg} / \mathrm{ha}$ recorded marginally higher monetary returns over its lower dose but it could not reach at the level of significance. While, the value of $\mathrm{B}$ : $\mathrm{C}$ ratio was obtained equal under different levels of phosphorus because of lower cost involvement with lower dose of phosphorus. The findings are in agreement with that of Daulagupu and Thakuria (2016).

\section{Production and economic efficiency}

Different levels of nitrogen have significantly influenced production efficiency and economic efficiency of mustard crop. Data pertaining to production efficiency and economic efficiency are presented in Table 2 revealed that the application of $80 \mathrm{~kg} \mathrm{~N} / \mathrm{ha}$ produced the highest production efficiency $(22.2 \mathrm{~kg} / \mathrm{ha} /$ day $)$ and economic efficiency ( $₹$ 635/ha/day) followed by $100 \mathrm{~kg}$ $\mathrm{N} / \mathrm{ha}$. Application of $80 \mathrm{~kg} \mathrm{~N} / \mathrm{ha}$ recorded higher seed yield and monetary returns may be responsible for good productivity and economic returns.

\section{Partial factor productivity}

Among the levels of nitrogen and phosphorus influenced significantly partial factor productivity of $\mathrm{N}$ and $\mathrm{P}$ (Table 2). However, reverse trend was recorded in respect of partial factor productivity of nitrogen and phosphorus. The lower level of nitrogen recorded higher productivity over the higher dose due to favoured better utilization of nutrients under lower dose of fertilizer and increased partial factor productivity. These results are in agreement with the earlier finding of Sudhalakshmi, 2009.

Thus, on the basis of above study it can be concluded that Indian mustard should be fertilize with $80 \mathrm{~kg} \mathrm{~N} / \mathrm{ha}$ and $40 \mathrm{~kg} \mathrm{P}_{2} \mathrm{O}_{5}$ for obtaining higher yield and economic returns.

\section{References}

Daulagupu, K., and Thakuria, K. 2016. Effect of planting geometry and fertilizer levels on yellow sarson (Brassica rapa var. trilocularis) under rainfed condition. Journal of Oilseed Brassica 7(2): 169-173.

Ghimire, T.B., and Bana, O.P.S. 2011. Effect of fertility levels on mustard (Brassica juncea) seed yield, quality and economics under varying poplar (Populus deltoides) tree densities. Indian Journal of Agronomy 56(4): 346-350.

Gomez, K.A., Gomez, A.A. 1984. Statistical Procedures for Agricultural Research. John Wiley \& Sons, Singapore.

Singh, Y., Sharma, D.K., Sharma, N.L. and Kumar, V. 2017. Effect of different levels of NPK with combined use of FYM and sulphur on yield, quality and nutrients uptake in Indian mustard (Brassica juncea L.). International Journal of Chemical Studies 5(2): 300-304.

Sudhalakshmi, C., 2009. Partial factor productivity of major nutrients on grain and straw of rice hybrids in SRI strategy. International Journal of Agricultural Sciences 5(2): 334-336.

\section{How to cite this article:}

Jat, A.L., K.P. Prajapati, B.K. Patel, P.J. Patel, J.R. Patel, S.K. Shah and Desai, A.G. 2017. Influence of NPK Levels on Performance of Indian Mustard (Brassica juncea L.). Int.J.Curr.Microbiol.App.Sci. 6(9): 1986-1990. doi: https://doi.org/10.20546/ijcmas.2017.609.243 